

\section{EDITORIAL ADVISORY BOARD}

Jamal Mohammed Ahmed, Ministry of Foreign Affairs, Sudan

Professor G. Balandier, University of Paris

K. E. BERRILL, University of Cambridge

Dr S. O. Brobak U, University of Lagos, Nigeria

Professor P. J. Bohannan, Northwestern University, Evanston

Propessor W. O. Brown, Boston University

Dr B. T. G. Chidzero, U.N. Technical Assistance Board, Kenya

Professor J. S. Colmman, Makerete University College, Uganda

Professor J. G. St Clair Drake, Roosevelt University, Chicago

THOMAS HODGRIN, University of Ghana

Joнn Holmes, Canadian Institute of International Affairs, Toronto

Dr Arthur Lewis, Princeton University

Professor G. T. LeYs, University of Sussex, Brighton

DR AB Doulaye Ly, I.F.A.N., University of Dakar

TAIÉ B SLIM, Tunisian Representative at the United Nations

Professor S. N. VARMA, University of Delhi

\section{CONTRIBUTIONS}

Contributions are invited from all over the world, and especially from scholars working in African universities. Articles written in languages other than English will be considered on their merits, and where necessary translation will be arranged. The average length suggested is 3,000 to 6,000 words, with occasional exceptions of up to 10,000 words. Notes on centres of African studies, research projects, and reports of recent conferences are also welcome.

All correspondence and contributions should be addressed to

The Editors, The Journal of Modern African Studies, at either University College, Dar es Salaam, Tanzania or University Press, Cambridge, England.

Each contributor will receive a copy of the number and 25 offprints of his article free of charge.

\section{SUBSCRIPTIONS}

Subscriptions (35s. net per annual volume of four parts, post free) are payable in advance, and may be sent to any bookseller, or to Cambridge University Press, Bentley House, 200 Euston Road, London, N.W.r. Subscribers in the U.S.A. should send their subscriptions (\$6.50 per volume) to the Cambridge University Press, American Branch, 32 East 57th Street, New York, N.Y. 10022. 


\section{South Africa}

\section{A Study in Conflict}

\section{By PIERRe L. VAN DEN Berghe}

\section{Author of Caneville: The Social Structure of a South African Town}

A socio-political analysis of South Africa, characterized by the author as "a large scale and extremely complex society in a state of acute and continuous conflict and disequilibrium." Mr. van den Berghe is associate professor of sociology at State University of New York, Buffalo. Contents: Introduction; The Historical Background; The Social Structure of Modern South Africa: Culture and Status; Polity and Economy; Socio-Political Conflicts: Afrikaners Versus English; "Native Policy"; The Non-White Opposition and the Internal Power Balance; The Economic System and its Dysfunctions; Value Conflicts; External Pressures; Some Theoretical Considerations; Chronology of South African Events; Statistics; International Resolutions Concerning Human Rights in South Africa; Selected Bibliography.

"A remarkably clear explanation of the conditions that exist in South Africa, the historical and sociological reasons for these conditions, and the attitudes behind them. The dominating conflict growing out of a rigid system of racial segregation imposed by the white minority can lead to but one terrible end. The book suggests that the reckoning may not be far off."-Library Fournal.

384 pages, Index, maps, notes, tables. L.C.65-1 $4053 \$ 8.95$

Wesleyan University Press

MIDDLETOWN, CONNEGTICUT $0645^{8}$ 


\section{JOURNAL OF NIGERIAN STUDIES}

A monthly periodical whose mission is to enrich knowledge about the most populous democratic State in Africa will soon be published under the auspices of private endeavour.

It will be a medium of information regarding trends in

$\begin{array}{ll}\text { AGRICULTURE } & \text { FISHERY } \\ \text { ANTHROPOLOGY } & \text { FORESTRY } \\ \text { ARCHAEOLOGY } & \text { GEOGRAPHY } \\ \text { BANKING } & \text { GEOLOGY } \\ \text { BUSINESS } & \text { HISTORY } \\ \text { DIPLOMACY } & \text { HOME ECONOMICS } \\ \text { ECONOMICS } & \text { JOURNALISM } \\ \text { EDUCATION } & \text { LANGUAGES } \\ \text { FINANCE } & \text { LAW } \\ \text { FINE ARTS } & \text { LITERATURE }\end{array}$

MUSIC

PHILOSOPHY

PHYSICAL EDUCATION

POLITICAL SCIENCE

PSYCHOLOGY

RELIGION

SCIENCE

SOCIOLOGY

TECHNOLOGY

VETERINARY SCIENCE

and other disciplines as they affect this colossus of Africa.

Among its features will be:

-Introduction to Encyclopaedia Nigeriana.

- Review of certain aspects of Nigerian history.

- Commentary on Nigerian law and procedure.

-Dictionary of Nigerian biography.

- Criticism of latest books and articles in periodicals relating to Nigeria.

- Collection of bibliographical literature on Nigeria.

- Chronological data on Nigeria.

-Articles affecting various facets of Nigerian life.

Payment will be made for accepted literary and graphic contributions at approved rates. Typescripts or manuscripts will be returned if they are accompanied by self-addressed and pre-stamped envelopes.

\section{AFRICAN BOOK COMPANY LIMITED}

\section{P.M.B. 12022 LAGOS, NIGERIA}




\section{New \\ Urbanization and Migration in West Africa}

Edited by HILDA KUPER. The processes of urbanization and migration in West Africa have long interested students of different disciplines and have evoked controversial interpretations among them. The essays in this book express the thoughts of a geographer, a historian, a linguist, anthropologists, sociologists, a political scientist, and an economist on the process of industrialization as it affects the patterns of migration to urban centers.

$\$ 6.95$

\section{Tunisia Since Independence}

The Dynamics of One-Party Government. CLEMENT HENRY MOORE. Can single-party régimes cope with the gigantic problems that modernization is creating in the new states? Mr. Moore seeks an answer to this question in his account of post-independence politics in Tunisia, the arena for one of the oldest and most politically mature of the new single-party régimes in Africa. He offers a perceptive analysis of the local and national politics of the country.

$\$ 6.00$

\section{The Samburu}

A Study of Gerontocracy in a Nomadic Tribe. PaUl spencer. The Samburu are a Masai-speaking tribe of some 30,000 persons in northern Kenya. This book examines their society, a gerontocracy in which power vests in the older men, while men under thirty may not marry or otherwise assert their personal independence.

$\$ 6.50$

\section{Recently Published}

POLITICAL PARTIES AND NATIONAL INTEGRATION IN TROPICAL AFRICA edited by James S. Coleman and Carl G. Rosberg

THE CAMEROONS from Mandate to Independence

Victor T. LeVine

FEDERAL GOVERNMENTIN NIGERIA. Eme O. Awa

POLITICAL AWAKENING IN THE CONGO. René Lemarchand

$\$ 7.95$

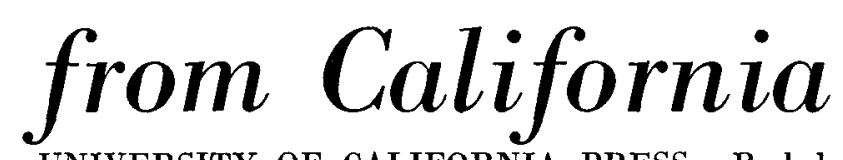

UNIVERSITY OF CALIFORNIA PRESS. Berkeley 94720 


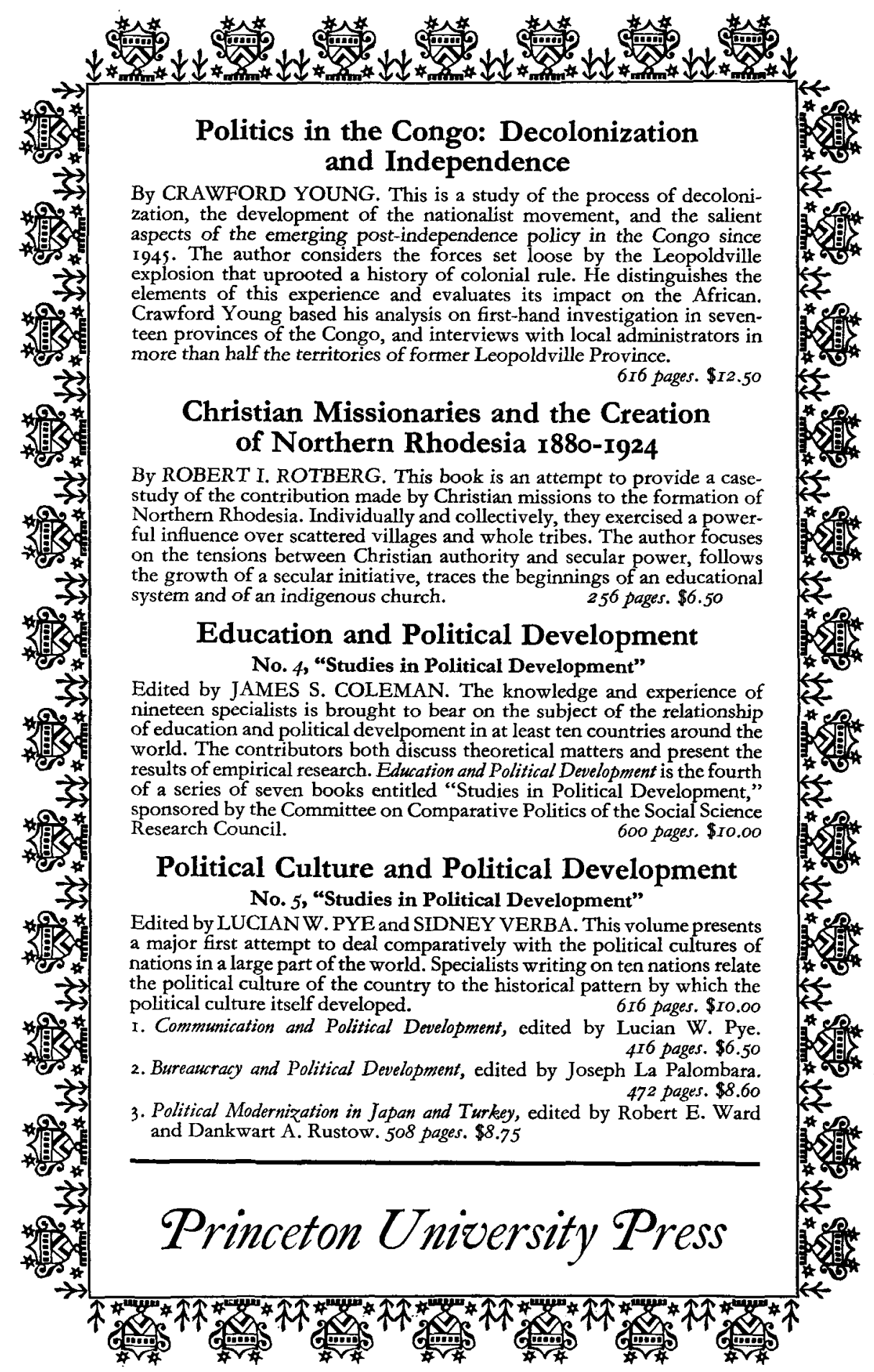




\section{THE JOURNAL OF MODERN AFRICAN STUDIES}

\begin{tabular}{lll}
\hline VOLUME 3 & AUGUST I 965 & NUMBER 2
\end{tabular}

\section{ARTICLES}

\section{THE POLITICS OF BOUNDARIES IN NORTH AND WEST}

AFRICA

DR I. Willtam zartman, Director of Graduate Studies, Institute of International Studies, University of South Carolina, Columbia

GOMMERCIAL BANKING IN EAST AFRICA, I 950-I963

DR HOLger L. ENGBerg, Assistant Professor of Finance, Graduate School of Business, New York University

CONTRADICTIONS IN THE NIGERIAN POLITIGAL

SYSTEM

DR RICHARD L. SKLAR, Lecturer in Political Science, University of Ibadan, Nigeria

WHAT IS THE PROBLEM ABOUT CORRUPTION?

GOLIN LEys, Professor of Politics, School of Social Studies, University of Sussex, Brighton

AFRIGAN ADVANGEMENT IN COMMERGE AND

INDUSTRY

D. S. PEARSON, Lecturer in Economics, University College of Rhodesia and $\mathcal{N}$ yasaland, Salisbury

\section{REVIEW ARTICLE}

FOUR AFRICAN DEVELOPMENT PLANS: GHANA, KENYA, NIGERIA, AND TANZANIA

DR REGINALD H. GREEN, Visiting Lecturer in Economics, University of Ghana, Legon

\section{AFRICANA}

Egonomic Development Research Projegt, Makerere University College, Kampala PROFESSOR PAUL G. CLARK, Williams College, Williamstown, Massachusetts

East African Institute of Social and Cultural Affairs, Nairobi DR BETHWELL A. OGOT, Department of History, The University College, Nairobi

Institut Africain pour le Développement Economique et Sogial, ABIDJAN P È E RENÉ BUREAU, I.N.A.D.E.S., Abidjan, Cốte-d'Ivoire

The Transcription Gentre, London DIANA SPEED, The Transcription Centre, London

Conference on the Use of Mass Media in the Education of aduits in Lusaka PETER TEMU, College of Social Studies, Kikuyu, Kenya

Golloque sur la Psychologie des Elites de l'Afrique Noire in Paris

J.-c. F о овн $\mathrm{LCH}$, Centre de hautes études administratives sur l'Afrique et l'Asie modernes, Paris

Volta ResetTLEMENT Symposium in Kumasi DR A. G. HOPKINS, Centre of West African Studies, University of Birmingham

Inaugural Conference of the African Training and Research Gentre in Administration for Development in Tangier PHILIP MAWHOOD, Centre africain de formation et de recherche administratives pour le développement, Tanger

CONFERENGE ON THE TEAGHING OF LAW in Ibadan J. T. HARRISON, Faculty of Law, University of Ife, Ibadan 


\section{REVIEWS}

Political Parties in French-speaking West Africa by Ruth SGHachter Morgenthau DR FRANCIS X. SUTton, The Ford Foundation, Nairobi

Ghana Resurgent by Michael Dei-Anang

Politics in Ghana, 1946-6o by Dennis Austin PROFESSOR HENRY L. BRETTON, Department of Political Science, University of Ghana, Legon

L'Afrique des africains by CLAUde WAUTHIER BASIL DAVIDSON, London

The Military in the Political Development of New Nations by MOR R IS J A NOW I z z Military Institutions and Power in the New States by WILLIA M G UT TE RIDGe E U E N E P. A. SCHLE H, International Relations Program, Yale University, New Haven

$L^{\prime}$ Economie des jeunes nations by Frangor S PER ROUX

Commerce exterieur et sous-développement by GUY DE LACHARR I È RE

Industrialisation au Maghreb by DE BE R IS et al.

Dix-huit leģons sur la société industrielle by RAYMOND ARON A. F. EWIN G, U.N. Economic Commission for Africa, Addis Ababa

The Economics of Underdevelopment by A. N. AG A R W A L A and S. P. S INGH Studies in Economic Development by B. OK UN and R. W. R XGHAR DSON

Leading I ssues in Development Economics by GE R A LD M. MEI E R ID I A N N. RESN ICK, Faculty of Social Science, The University College, Dar es Salaam

The United States and the Italo-Ethiopian Crisis by BrIGE HARRIS, JR. D R R I CH A R D PA N K H U R S T, Institute of Ethiopian Studies, Haile Selassie I University, Addis Ababa

Haile Selassie I: the Conquering Lion by Leon A R DOSLEY PERCY ARNOLD, Addis Ababa

Modern Poetry from Africa edited by Gerald MOORE and ULLI BeIER A Book of African Verse compiled and edited by JoHN REED and CLIVE WAKE Poems from Black Africa edited by LANG STON HUGHES

Schwarzer Orpheus: Neue Sammlung selected and rendered by J A N HEIN z J A H N ROLAND HINDMARSH, Cambridge

Africa Report

LEWIS N KOSI, 'The New African', London 